\title{
REGULATION OF IRRIGATION WATER QUALITY CAN FURTHER IMMOBILIZE CD IN CONTAMINATED SOILS
}

\author{
Li, P. ${ }^{1}-$ ZhANG, Y. ${ }^{2}-$ LiU, D. ${ }^{3}-$ GUO, W. ${ }^{3}-$ LI, K. Y. ${ }^{1}-$ ZhANG, Z. L. ${ }^{4}-$ QI, X. B. ${ }^{1,3^{*}}-$ ZHAO, Z. J. \\ ${ }^{1}$ Institution Laboratory of Quality and Safety Risk Assessment for Agro-Products on Water \\ Environment Factors, Ministry of Agriculture and Rural Affairs, Xinxiang 453002, China
}

${ }^{2}$ Farmland Irrigation Research Institute, Chinese Academy of Agricultural Sciences, Xinxiang, Xinxiang 453002, China

${ }^{3}$ Agriculture Water and Soil Environmental Field Science Research Station, Chinese Academy of Agricultural Sciences, Xinxiang, Xinxiang 453002, China

${ }^{4}$ The James Hutton Institute, Craigiebuckler, Aberdeen AB15 8QH, United Kingdom

\author{
${ }^{*}$ Corresponding author \\ e-mail: qxb6301@sina.cn; phone: +86-373-3393-402
}

(Received 21 $1^{\text {st }}$ May 2020; accepted $17^{\text {th }}$ Sep 2020)

\begin{abstract}
Combined use of surface water and groundwater is a common practice in agricultural activities, but how the immobilize cadmium and its decrease in grains induced with irrigation micro-polluted surface water and groundwater is still poorly understood. This paper presents field experimental results in attempts to reveal the effect of irrigation water quality on cadmium migration and accumulation in winter wheat/summer maize rotation systems in Huabei plain while the cadmium content in $0-10 \mathrm{~cm}$ topsoil is 3.8 times, permissible value for agricultural land in China. The results showed there was no obviously influence on cadmium accumulation in grains irrigated with micro-polluted surface water during emergence and seeding stage, but there was significantly increased $\mathrm{Cd}$ content and a higher bioaccumulation factor in grains with micro-polluted surface water irrigation during jointing and booting stage. It was found a significantly inhibition for grain weight and uniformity with groundwater irrigation during jointing and booting stage, and winter wheat yield was significantly decreased with micro-polluted surface water irrigation during jointing and booting stage. It could be concluded irrigation water type can further immobilize $\mathrm{Cd}$ in mild and moderate contaminated soils, thus micro-polluted surface water can be adopted in seeding stage, and groundwater irrigated in jointing and booting stage at heavy metal pollution arable farmland to minimize the risk of biological chain pollution and food safety.
\end{abstract}

Keywords: cadmium, irrigation schedule, micro-polluted surface water, groundwater, bio-concentration factor, bio-accumulation factor

\section{Introduction}

Soil heavy metals are a common abiotic stress inhibiting crop growth. Heavy metals in the soil not only pose a serious threat to the quality of cultivated land and agricultural products, through the food chain they ultimately threat the health of human beings (Yang et al., 2018; Peng et al., 2019; Huang et al., 2019). Due to its estrogen-like activity, exposure levels of 30-50 mu g per day have been estimated for adults and these levels have been linked to increased risk of bone fracture, cancer, kidney dysfunction and hypertension (Satarug et al., 2003; Franz et al., 2008), yet according to a case-control study, cadmium might be related to a decreased risk of ER- and ER-/PRbreast tumors (Amadou et al., 2020). Especially, a very strong Cd contamination in fish organs (gills, posterior intestine, liver, kidneys and skeletal muscle) collected downstream from the metal source (Andres et al., 2000), moreover, the period of 
ripening of sexual products led to an increase of condition index and to a decrease of $\mathrm{Cd}$ concentrations in the whole soft tissues of clams from both sites, hence reflecting the phenomenon of "biological dilution" (Smaoui-Damak et al., 2006). According to the results of the Ministry of Environmental Protection and the Ministry of Land and Resources' National Survey on Soil Pollution Status from China in 2014, the quality of cultivated soil in China is worrying. The total over-standard rate of soil in China is $16.1 \%$ and the pollution is mainly caused by inorganic heavy metals. The number of inorganic pollutants accounted for $82.8 \%$ of all over-standard points. At present, the over-standard rate of cultivated soil in China has reached $19.4 \%$, among which the moderate to light pollution points account for $94.33 \%$ of the total pollution points, mainly including 8 pollutants such as $\mathrm{Cd}, \mathrm{Ni}$ and $\mathrm{Cu}$ (Chen et al., 2017).

The Huabei Plain is an important grain production base and grain production accounts for $23.6 \%$ of China grain yield (Yin et al., 2016), which benefits from long-term high water and fertilizer input, agronomy technology and agricultural management since the 1980s (Chen et al., 2014; Wang et al., 2018a). Global climate change has resulted in more uncertainty in agricultural production systems, which cause potential risk to both food security and natural ecosystems (Hundecha and Bardossy, 2005; Wang et al., 2018b). Based on daily precipitation data from 63 national meteorological stations on the Huabei Plain from 1963 to 2012, the precipitation has since been in decline at a rate of $0.8 \mathrm{~mm} /$ per annum, the uncertainty of changes is more obvious due to the climate change ( $\mathrm{Li}$ et al., 2015, 2018). That's to say, micro-polluted surface water needed to be used for food security, but the average $\mathrm{Cd}$ concentration in the micro-polluted surface water and groundwater is 21.6 and $0.5 \mu \mathrm{g} / \mathrm{L}$ respectively $(\mathrm{Hu}$ et al., 2016), and approximately 43 times of $\mathrm{Cd}$ enters the district via micro-polluted surface water irrigation compared with groundwater irrigation. Rotational irrigation management is therefore essential to block the migration of heavy metals to plant bodies (Li et al., 2014). As in most irrigation areas, groundwater pumped for agricultural irrigation is the main way to solve the shortage of agricultural water for food production in China (Kong et al., 2016; Yin et al., 2017), conjunctive use of micro-polluted surface water and groundwater in this area is to block $\mathrm{Cd}$ induced by irrigation with the micro-polluted surface water because the groundwater is relatively less $\mathrm{Cd}$ contamination and higher salt content to hinder soluble salts in soil moving into the plant bodies (Li et al., 2014; Arefin et al., 2016; Zhang et al., 2018). The key parameters for managing water usage in the area are bio-concentration factor (BCF) and bio-accumulation factor (BAF) (Safahieh, 2018), we will define BAF here ratio of Cd content in grain and the above-ground plants to the 0 to $40 \mathrm{~cm}$ soil layers.

Therefore, the overarching purposes of this paper are (1) to investigate cadmium accumulation in crop-soil system induced with micro-polluted surface water/groundwater irrigation; and (2) to reveal irrigation schedule with micro-polluted surface water/groundwater to ensure grain quality in typical rotation system of Huabei plain, China.

\section{Materials and Methods}

\section{The study area}

With Chinese economic fast development from 1980s, it has substantially increased water demand for this region which cannot be met from natural recharge to surface and subsurface watercourse as the average annual precipitation in the area was only $550 \mathrm{~mm}$ 
since 1980s (Li et al., 2015). Currently, border irrigation with conjunctive use of micropolluted surface water and groundwater is the dominant irrigation technology in the area. For food security in China, reclaimed water and sewage water from surface rivers participated in agricultural production, a clear increase in the quantity of annual wastewater recycled and reused was observed during the last decade, reaching 3.5 billion $\mathrm{m}^{3}$ account for $1.60 \%$ of total agricultural water consumption in 2013 (Wang et al., 2017). The lasted research results of heavy metal contamination of cultivated soils in Huabei Plain showed exceedance percentages was $12.22 \%$ and the proportion of $\mathrm{Cd}$, $\mathrm{Ni}, \mathrm{Cu}, \mathrm{Zn}$, and $\mathrm{Hg}$ increased by $16.07 \%, 4.56 \%, 3.68 \%, 2.24 \%$, and $1.96 \%$, respectively (Shang et al., 2018).

The experiment was carried out in a typical winter wheat /summer maize rotation system area (latitude $35^{\circ} 23^{\prime} 45^{\prime \prime} \mathrm{N}$, longitude $113^{\circ} 59^{\prime} 31^{\prime \prime} \mathrm{E}$, and altitude $70 \mathrm{~m}$ ) in Weihe irrigation district, Xinxiang city Henan Province, China from 2012 to 2013. The basic physical and chemical properties of the soil of the study area site are shown in Table 1. The winter wheat variety AiKang 58 was planted on October 8 and 2012, harvested on June 6, 2013, and the whole growth period was 241 days. According to the soil fertility status and target yield of the experimental site, urea $(\mathrm{TN} \geq 46.4 \%) 300 \mathrm{~kg} / \mathrm{hm}^{2}$ and compound fertilizer $\left(\mathrm{N}-\mathrm{P}_{2} \mathrm{O}_{5}-\mathrm{K}_{2} \mathrm{O}=16 \%: 22 \%: 10 \%\right) 750 \mathrm{~kg} / \mathrm{hm}^{2}$ was applied as base fertilizer, and urea $225 \mathrm{~kg} / \mathrm{hm}^{2}$ was applied as topdressing at the jointing stage. The summer maize variety DanFu 6 was tested, planted on June 8, 2013, harvested on September 26, 2013, the whole growth period was 110 days, and the summer maize jointing stage was applied with urea $600 \mathrm{~kg}$ per hectare. The row spacing of winter wheat and summer maize is $20 \mathrm{~cm}, 60 \mathrm{~cm}$, respectively, and the sowing rate for winter wheat and summer maize is $150 \mathrm{~kg}, 45 \mathrm{~kg}$ per hectare, respectively. The average annual precipitation in the region is $580 \mathrm{~mm}$, of which $70 \%$ falls between June and September; the average annual evaporation measured from the $30 \mathrm{~cm}$ pan is $1860 \mathrm{~mm}$. Irrigation is usually needed in the dry seasons including January, March, May and June at the withering, jointing and grain-filling stages of the winter wheat, with irrigation amount varying from $750 \mathrm{~m}^{3} / \mathrm{hm}^{2}$ to $1000 \mathrm{~m}^{3} / \mathrm{hm}^{2}$ depending on soil moisture and the potential demand of water for the crops. The precipitation occurred in the study period was shown in Fig. 1.

Table 1. Basic physical and chemical properties of the soil at the study area

\begin{tabular}{c|c|c|c|c|c|c|c|c}
\hline $\begin{array}{c}\text { Soil layer } \\
\text { depth } \\
(\mathrm{cm})\end{array}$ & $\begin{array}{c}\text { Available } \\
\mathbf{C d} \\
\left(\mathrm{mg} \cdot \mathrm{kg}^{-1}\right)\end{array}$ & $\begin{array}{c}\text { Total Cd } \\
\left(\mathrm{mg} \cdot \mathrm{kg}^{-1}\right)\end{array}$ & $\mathbf{p H}$ & $\begin{array}{c}\text { TN } \\
\left(\mathrm{g} \cdot \mathrm{kg}^{-1}\right)\end{array}$ & $\begin{array}{c}\text { TP } \\
\left(\mathrm{g} \mathrm{kg}^{-1}\right)\end{array}$ & $\begin{array}{c}\mathbf{O M} \\
\left(\mathrm{g} \cdot \mathrm{kg}^{-1}\right)\end{array}$ & Soil texture & $\begin{array}{c}\text { Bulk density } \\
\left(\mathrm{g} \cdot \mathrm{cm}^{-3}\right)\end{array}$ \\
\hline $0-10$ & 1.6505 & 2.2678 & 8.00 & 0.95 & 1.16 & 19.90 & Silt clay & 1.40 \\
$10-20$ & 0.1915 & 0.3388 & 8.05 & 0.46 & 0.58 & 9.90 & Silt clay & 1.41 \\
$20-30$ & 0.0345 & 0.1110 & 8.10 & 0.39 & 0.52 & 8.60 & Silt clay & 1.43 \\
$30-40$ & 0.0083 & 0.0852 & 8.06 & 0.35 & 0.46 & 7.80 & Silt clay & 1.43 \\
\hline
\end{tabular}

\section{Experimental design}

According to local irrigation schedule and production habits, the winter wheat needs supplementary irrigation during emergence stage, jointing stage and booting stage, and the summer maize during seeding stage. Two irrigation water sources were available for the experiments, namely micro-polluted surface water and groundwater (W stands for micro-polluted surface water and T stands for groundwater). WTT represents micropolluted surface water irrigation at the emergence stage, and groundwater irrigation at 
the jointing and booting stage. $\mathrm{CK}$ represents groundwater irrigation at the emergence stage, jointing and booting stage. The field trial was a fully randomized design with three replicates of eight treatments using micro-polluted surface water and groundwater irrigation with border irrigation. Each experiment plot area is 100 square meters. Other management practices during the whole growth season were completely consistent.

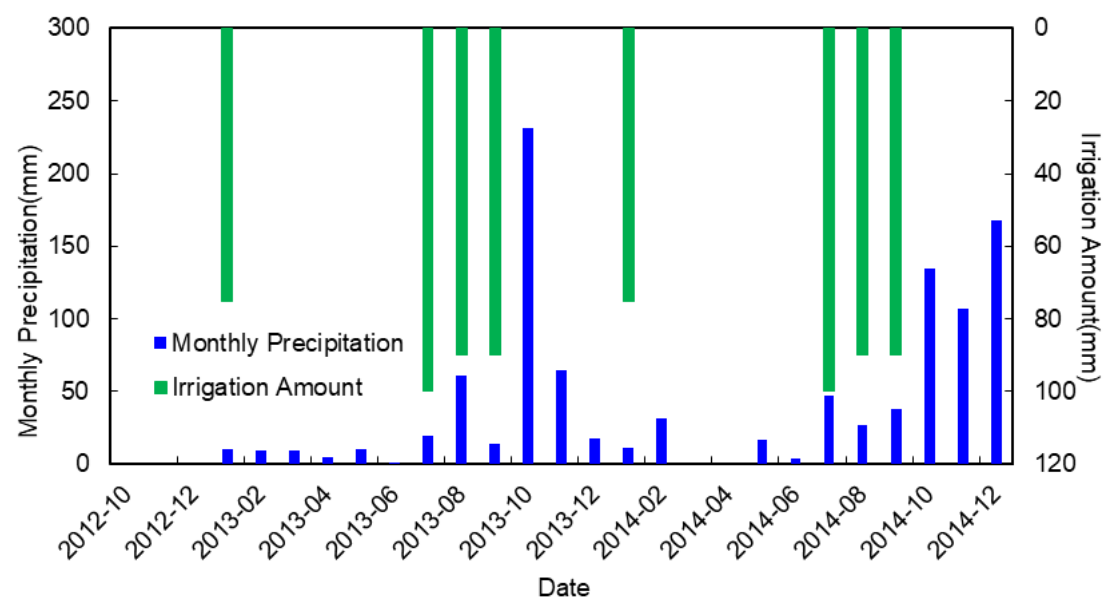

Figure 1. Change of monthly irrigation and precipitation within the experimental site

The experiment design was shown in Table 2. The ingredient of irrigation water sources was shown in Table 3.

Table 2. Experiment design in the study area

\begin{tabular}{c|c|c|c|c}
\hline Growth stage & Emergence stage & Jointing stage & Booting stage & Seeding stage \\
\hline Irrigation date & $2012-10-18$ & $2013-4-3$ & $2013-5-2$ & $2013-6-15$ \\
\hline Days after sowing & 7 & 174 & 203 & 8 \\
Irrigation amount & 750 & 1000 & 900 & 900 \\
$\left(\mathrm{~m}^{3} \cdot \mathrm{hm}^{-2}\right)$ & MPSW & GW & GW & MPSW \\
WTT & GW & MPSW & GW & MPSW \\
TWT & GW & GW & MPSW & MPSW \\
TTW & MPSW & MPSW & GW & MPSW \\
WWT & MPSW & GW & MPSW & MPSW \\
WTW & GW & MPSW & MPSW & MPSW \\
TWW & GW & GW & GW & MPSW \\
CK & MPSW & MPSW & MPSW & MPSW \\
WWW &
\end{tabular}

*MPSW means micro-polluted surface water, GW means groundwater

Table 3. Composition of irrigation water used in the field experiment

\begin{tabular}{c|c|c|c|c|c|c|c|c|c|c}
\hline $\begin{array}{c}\text { Irrigation } \\
\text { type }\end{array}$ & $\begin{array}{c}\mathbf{C l}^{-} \\
\left(\mathrm{mg} \cdot \mathrm{L}^{-1}\right)\end{array}$ & $\begin{array}{c}\mathbf{K}^{+} \\
\left(\mathrm{mg} \cdot \mathrm{L}^{-1}\right)\end{array}$ & $\begin{array}{c}\mathbf{T N} \\
\left(\mathrm{mg} \cdot \mathrm{L}^{-1}\right)\end{array}$ & $\begin{array}{c}\mathbf{P b}^{2+} \\
\left(\mathrm{mg} \cdot \mathrm{L}^{-1}\right)\end{array}$ & $\begin{array}{c}\mathbf{C u}^{2+} \\
\left(\mathrm{mg}^{2+} \mathrm{L}^{-1}\right)\end{array}$ & $\begin{array}{c}\mathbf{C d}^{2+} \\
\left(\mu \mathrm{g} \cdot \mathrm{L}^{-1}\right)\end{array}$ & $\begin{array}{c}\mathbf{C r}^{\mathbf{6}+} \\
\left(\mu \mathrm{g} \cdot \mathrm{L}^{-1}\right)\end{array}$ & $\begin{array}{c}\mathbf{C O D} \mathbf{M n} \\
\left(\mathrm{mg} \cdot \mathrm{L}^{-1}\right)\end{array}$ & $\mathbf{p H}$ & $\begin{array}{c}\mathbf{S a l i n i t y} \\
\left(\mathrm{g} \cdot \mathrm{L}^{-1}\right)\end{array}$ \\
\hline GW & 321.27 & 18.67 & 17.16 & 0.0015 & 0.005 & 0.5 & 3.4 & 40.66 & 7.30 & 1.85 \\
MPSW & 291.42 & 13.26 & 23.17 & 0.0020 & 0.006 & 21.6 & 2.5 & 54.35 & 7.32 & 1.51 \\
$\mathrm{~GB}^{*}$ & 350 & - & - & 0.2 & 1 & 10 & 100 & 200 & $5.5-8.5$ & 2 \\
\hline
\end{tabular}

*GB represent Standards for irrigation water quality (GB 5084-2005) 


\section{Sampling and measurement}

Soil samples were collected before winter wheat planting, winter wheat harvesting, and summer maize harvesting, for detecting available cadmium content and total cadmium content. At each sample, there were further five sub-sampling points scattered uniformly over an area of $100 \mathrm{~m}^{2}$. At each sampling point, soil was cored using a $3.5 \mathrm{~cm} \varnothing$ soil auger at an interval of $10 \mathrm{~cm}$ down to the depth of $40 \mathrm{~cm}$; approximately 100-200 g fresh soil was collected from each interval. The soils cored from the same depth from all the five sampling points at the same experimental plot were pooled and then stored in an aseptic bag before being shipped to the laboratory. The samples were then air dried at room temperature for one week and the electrical conductivity of each sample was measured based on the standard protocol from the 5:1 (w/v) water/soil extract (Rhoades et al., 1989). The $\mathrm{pH}$ was measured using a $\mathrm{pH}$ meter (PHSJ-5, Leici, Shanghai, China), the EC was measured using a conductivity meter (DDSJ-308A, Leici, Shanghai, China). The available $\mathrm{Cd}$, Total $\mathrm{Cd}$ were measured using atomic absorption spectrometer (AA-7000, SHIMADZU, Kyoto, Japan).

Ten square meters was selected as the production area in each treatment, and the indexes of winter wheat yield, 1000-grain weight, dry matter weight and root weight were determined. 100 winter wheat plants were randomly selected to measure the $\mathrm{Cd}$ content in different parts (roots, stems, leaves and grain) of the plant. 20 summer maize were randomly selected for each treatment, and the yield, 100-grain weight, dry matter weight, root weight and Cd content in different parts (root, stem, leaves, package, grain) were determined. Dry matter weight was determined by oven drying method, with temperatures set at $105{ }^{\circ} \mathrm{C}$ for $0.25 \mathrm{~h}$ and $70{ }^{\circ} \mathrm{C}$ for $20 \mathrm{~h}$. The determined method of $\mathrm{Cd}$ content in plants was similar to soil samples.

\section{Data processing and calculation}

Data were analyzed by Excel 2013 and DPS Statistical software package. Two-way analysis of variance (ANOVA) was performed with the general linear model procedure to calculate the effects of irrigation water type and irrigation period on the investigated parameters. When the $\mathrm{F}$ value was significant, a multiple means comparison was performed with Duncan's new multiple range test $(\mathrm{p}<0.05)$. The graphs were generated using Microsoft Excel 2013, and the standard error of the mean were calculated and presented in the tables.

$\mathrm{Cd}$ accumulation related indicators in soil and plant were calculated from:

$$
\begin{gathered}
C d_{g}=C_{g} Y \\
C d_{s l}=C_{s l} Y_{s l} \\
C d_{s}=4 \rho C_{s} \\
R_{r / s}=\frac{C_{r}}{C_{s}}
\end{gathered}
$$




$$
\begin{gathered}
B C F=\frac{C_{s l}}{C_{s}} \\
B A F=\frac{\left(C d_{g}+C d_{s l}\right)}{10^{6} \times C d_{s}}
\end{gathered}
$$

where $C d_{g}, C d_{s l}, C d_{s}, C_{g}, C_{s l}, C_{s}, C_{r}, Y, Y_{s l}, R_{r / s}, \rho, B C F, B A F$ is $\mathrm{Cd}$ accumulation in grain $\left(\mathrm{mg} / \mathrm{hm}^{2}\right), C d$ accumulation in the above-ground plants $\left(\mathrm{mg} / \mathrm{hm}^{2}\right)$, Cd accumulation in the 0 to $40 \mathrm{~cm}$ layer $\left(\mathrm{mg} / \mathrm{hm}^{2}\right)$, content in grain $(\mathrm{mg} / \mathrm{kg})$, content in the above-ground plants $(\mathrm{mg} / \mathrm{kg})$, content in the 0 to $40 \mathrm{~cm}$ layer $(\mathrm{mg} / \mathrm{kg})$, content in the root $(\mathrm{mg} / \mathrm{kg})$, yield of summer maize $\left(\mathrm{kg} / \mathrm{hm}^{2}\right)$, biomass of the above-ground plants $\left(\mathrm{kg} / \mathrm{hm}^{2}\right)$, ratio of Cd content in root and 0 to $40 \mathrm{~cm}$ soil layer, soil density $\left(\mathrm{g} / \mathrm{cm}^{3}\right)$, bio-concentration factor (BCF) (Yadav et al., 2017) and bio-accumulation factor (BAF) (Safahieh, 2018) (\%), respectively.

\section{Results and Discussion}

\section{The effect of different treatments on Cd content in winter wheat and summer maize}

The Cd content in roots, stems, leaves and grains of winter wheat under different treatments was shown in Table 4. The cumulative characteristics of $\mathrm{Cd}$ content in winter wheat plants indicated that the content of $\mathrm{Cd}$ in roots was the highest, accounting for $57.94 \%$ to $75.52 \%$ of the above-ground plants, followed by leaves, stems and grains, and the content of $\mathrm{Cd}$ in grains was the lowest, accounting for $1.55 \%$ to $4.09 \%$ of the above-ground plants.

\begin{tabular}{|c|c|c|c|c|}
\hline Treatment & $\operatorname{root}\left(\mathrm{mg} \cdot \mathrm{kg}^{-1}\right)$ & stem $\left(\mathrm{mg} \cdot \mathrm{kg}^{-1}\right)$ & leaves $\left(\mathrm{mg} \cdot \mathrm{kg}^{-1}\right)$ & grain $\left(\mathrm{mg} \cdot \mathrm{kg}^{-1}\right)$ \\
\hline TTW & $4.070 \pm 0.909 \mathrm{ab}$ & $0.299 \pm 0.084 c$ & $0.880 \pm 0.106 \mathrm{c}$ & $0.141 \pm 0.028 \mathrm{de}$ \\
\hline CK & $2.036 \pm 0.104 c$ & $0.231 \pm 0.029 \mathrm{c}$ & $0.659 \pm 0.052 \mathrm{c}$ & $0.083 \pm 0.001 \mathrm{f}$ \\
\hline WTT & $4.300 \pm 0.436 \mathrm{ab}$ & $0.283 \pm 0.045 \mathrm{c}$ & $1.200 \pm 0.200 \mathrm{~b}$ & $0.091 \pm 0.003 \mathrm{ef}$ \\
\hline TWT & $4.200 \pm 1.000 \mathrm{ab}$ & $0.490 \pm 0.095 \mathrm{ab}$ & $1.200 \pm 0.100 \mathrm{~b}$ & $0.133 \pm 0.009 \mathrm{def}$ \\
\hline TWW & $3.453 \pm 0.162 b$ & $0.490 \pm 0.0240 \mathrm{ab}$ & $1.773 \pm 0.214 \mathrm{a}$ & $0.244 \pm 0.048 \mathrm{ab}$ \\
\hline WWT & $3.453 \pm 0.428 b$ & $0.537 \pm 0.045 \mathrm{a}$ & $1.521 \pm 0.275 \mathrm{ab}$ & $0.174 \pm 0.010 \mathrm{~cd}$ \\
\hline WTW & $4.622 \pm 0.683 \mathrm{a}$ & $0.417 \pm 0.027 b$ & $1.230 \pm 0.194 b$ & $0.203 \pm 0.047 b c$ \\
\hline WWW & $4.808 \pm 0.297 \mathrm{a}$ & $0.581 \pm 0.032 \mathrm{a}$ & $1.230 \pm 0.112 b$ & $0.263 \pm 0.037 \mathrm{a}$ \\
\hline \multicolumn{5}{|c|}{ Significance based on two-way analysis of variance (ANOVA) ( $F$ value) } \\
\hline W (water type) & $1.210 *$ & $5.861 *$ & $13.491 * *$ & $35.886 * *$ \\
\hline S (growth stage) & $1.604 *$ & $0.574 *$ & 2.714 & 0.246 \\
\hline $\mathrm{W} \times \mathrm{S}$ & $1.526^{*}$ & 3.716 & 2.933 & $6.204^{*}$ \\
\hline
\end{tabular}

Table 4. Cd content in winter wheat plants under different treatments

Note: Different letters after the same column data indicate the difference between the treatments at the 0.05 level (Duncan new complex range method), the same below. **, Significance at the $\mathrm{p}<0.01, \mathrm{p}<$ 0.05 , respectively

The content of $\mathrm{Cd}$ in stems and grains treated by WTT was no significantly difference than that of CK treatment, but the content of $\mathrm{Cd}$ in roots and leaves treated by WTT was significantly higher than that of CK treatment, which increased by 2.11 and 1.82 times, respectively. The Cd content in grain treated by WTT was significantly 
lower than TWW, WWT, WTW and WWW treatment. Furthermore, the Cd content in grain treated by WTT was lower than that of TTW and TWT, which decreased by $35.17 \%, 31.38 \%$, respectively.

The Cd content in roots, stems, leaves, corn coating and grains of summer maize under different treatments was shown in Table 5. The cumulative characteristics of $\mathrm{Cd}$ content in summer maize plants indicated that the content of $\mathrm{Cd}$ in roots was the highest, accounting for $36.05 \%$ to $58.83 \%$ of the above-ground plants, followed by leaves, corn coating, stems and grains, and the content of $\mathrm{Cd}$ in grains was the lowest, accounting for $0.25 \%$ to $0.60 \%$ of the above-ground plants. The content of $\mathrm{Cd}$ in stems, leaves and grains treated by WTT was no significant difference from that in CK treatment, but the content of $\mathrm{Cd}$ in roots and corn coating treated by WTT was significantly higher than that in CK treatment, which increased by 1.90 and 1.59 times respectively. The Cd content in grain treated by WTT was significantly lower than TWT, TWW, WWT, WTW and WWW treatment. Furthermore, the Cd content in grain treated by WTT was lower than that in TTW, TWT, which decreased by $26.47 \%, 51.75 \%$, respectively. It showed that the $\mathrm{Cd}$ content in grains was increased significantly by irrigation with micro-polluted surface water during jointing and booting stage, which may be due to the lower content of chloride ions and higher content of TN in micro-polluted surface water compared with groundwater (Jiang et al., 2019).

Table 5. Cd content in summer maize plants under different treatments

\begin{tabular}{|c|c|c|c|c|c|}
\hline Treatment & $\operatorname{root}\left(\mathrm{mg} \cdot \mathrm{kg}^{-1}\right)$ & stem $\left(\mathbf{m g} \cdot \mathbf{k g}^{-1}\right)$ & leaves $\left(\mathrm{mg} \cdot \mathrm{kg}^{-1}\right)$ & $\begin{array}{c}\text { corn coating } \\
\left(\mathrm{mg} \cdot \mathrm{kg}^{-1}\right)\end{array}$ & grain $\left(\mathrm{mg} \cdot \mathrm{kg}^{-1}\right)$ \\
\hline TTW & $1.870 \pm 0.110 \mathrm{~cd}$ & $0.176 \pm 0.011 b c$ & $0.898 \pm 0.151 b$ & $0.475 \pm 0.048 \mathrm{de}$ & $0.013 \pm 0.002 \mathrm{c}$ \\
\hline CK & $1.123 \pm 0.119 \mathrm{f}$ & $0.120 \pm 0.049 c$ & $0.689 \pm 0.187 b$ & $0.365 \pm 0.020 \mathrm{e}$ & $0.009 \pm 0.001 \mathrm{c}$ \\
\hline WTT & $2.133 \pm 0.208 b c$ & $0.124 \pm 0.033 c$ & $0.780 \pm 0.060 \mathrm{~b}$ & $0.580 \pm 0.010 \mathrm{~cd}$ & $0.009 \pm 0.001 \mathrm{c}$ \\
\hline TWT & $2.400 \pm 0.200 \mathrm{~b}$ & $0.227 \pm 0.064 \mathrm{abc}$ & $0.920 \pm 0.171 b$ & $0.637 \pm 0.015 \mathrm{bcd}$ & $0.019 \pm 0.004 b$ \\
\hline TWW & $2.753 \pm 0.208 \mathrm{a}$ & $0.266 \pm 0.048 \mathrm{ab}$ & $1.680 \pm 0.140 \mathrm{a}$ & $0.880 \pm 0.092 \mathrm{a}$ & $0.024 \pm 0.001 \mathrm{ab}$ \\
\hline WWT & $2.333 \pm 0.081 \mathrm{~b}$ & $0.252 \pm 0.012 \mathrm{ab}$ & $1.520 \pm 0.139 a$ & $0.776 \pm 0.108 \mathrm{ab}$ & $0.019 \pm 0.001 \mathrm{~b}$ \\
\hline WTW & $1.528 \pm 0.233 \mathrm{e}$ & $0.276 \pm 0.098 \mathrm{ab}$ & $1.587 \pm 0.162 \mathrm{a}$ & $0.705 \pm 0.122 b c$ & $0.024 \pm 0.006 \mathrm{ab}$ \\
\hline WWW & $1.677 \pm 0.112 \mathrm{de}$ & $0.312 \pm 0.105 \mathrm{a}$ & $1.720 \pm 0.302 \mathrm{a}$ & $0.915 \pm 0.166 \mathrm{a}$ & $0.028 \pm 0.005 \mathrm{a}$ \\
\hline \multicolumn{6}{|c|}{ Significance based on two-way analysis of variance (ANOVA) ( $F$ value) } \\
\hline $\begin{array}{l}\mathrm{W} \text { (water } \\
\text { type) }\end{array}$ & $1.462 *$ & $3.622 *$ & 20.32 & $3.524 *$ & $13.432 * *$ \\
\hline S (stage) & $1.268 *$ & 0.665 & 2.641 & 0.632 & 0.123 \\
\hline $\mathrm{W} \times \mathrm{S}$ & $1.328 *$ & $1.572 *$ & $12.347 *$ & $1.468 *$ & $3.204^{*}$ \\
\hline
\end{tabular}

\section{The effect of different treatments on Cd BAF and BCF of summer maize}

The $\mathrm{Cd}$ BAF and bio-concentration factor of summer maize under different treatments were shown in Table 6. There was no significant difference between $\mathrm{Cd}$ accumulation in grain of WTT and CK treatment, but the Cd accumulation in grain of WTT was significantly lower than TTW, TWT, TWW, WWT, WTW and WWW treatment, decreased by $21.89 \%, 50.15 \%, 57.86 \%, 47.39 \%, 58.34 \%$ and $61.85 \%$, respectively. And the same rule appeared in above-ground $\mathrm{Cd}$ accumulation between treatments, the $\mathrm{Cd}$ accumulation in above-ground of WTT was significantly lower than TTW, TWT, TWW, WWT, WTW and WWW treatment, decreased by $26.08 \%, 44.95 \%$, $49.47 \%, 48.15 \%, 52.51 \%$ and $56.44 \%$, respectively. The content in the 0 to $40 \mathrm{~cm}$ soil layer of WTT treatment was significantly higher than CK, and the content of WTT treatment was obviously lower than TWW, WWT, WTW and WWW, decreased by 
$1.30 \%, 1.12 \%, 1.09 \%$ and $1.75 \%$, respectively. And then ratio of Cd content in root and 0 to $40 \mathrm{~cm}$ soil layer of WTT treatment was significantly higher than TTW, CK, WTW and WWW, increased by $13.94 \%, 47.10 \%, 28.80 \%$ and $22.40 \%$, respectively. Especially, BCF of WTT treatment was obviously lower than CK, TWT and TWW, decreased by $28.35 \%, 12.04 \%$ and $32.55 \%$, respectively. But the BAF between WTT and CK treatment was no significant difference, and BAF of WTT was obviously lower than TTW, TWT, TWW, WWT, WTW and WWW, decreased by $26.27 \%, 44.46 \%$, $49.78 \%, 47.70 \%, 50.83 \%$ and $54.75 \%$, respectively.

Table 6. $C d B A F$ and BCF of summer maize under different treatments

\begin{tabular}{c|c|c|c|c|c|c}
\hline Treatment & $\begin{array}{c}\mathbf{C d}_{\mathrm{g}} \\
\left(\mathrm{mg} \cdot \mathrm{hm}^{-2}\right)\end{array}$ & $\begin{array}{c}\mathbf{C d} \mathbf{d}_{\mathrm{sl}} \\
\left(\mathrm{mg} \cdot \mathrm{hm}^{-2}\right)\end{array}$ & $\begin{array}{c}\mathbf{C d} \\
\left(\mathrm{kg} \cdot \mathrm{hm}^{-2}\right)\end{array}$ & $\mathbf{R}_{\mathbf{r} / \mathrm{s}}$ & BCF & BAF \\
\hline TTW & $98.697 \pm 10.86 \mathrm{~d}$ & $1530.245 \pm 75.25 \mathrm{e}$ & $3.195 \pm 0.005 \mathrm{c}$ & $3.279 \pm 0.160 \mathrm{~d}$ & $0.684 \pm 0.032 \mathrm{~d}$ & $0.051 \pm 0.002 \mathrm{~d}$ \\
CK & $77.093 \pm 7.71 \mathrm{e}$ & $1132.695 \pm 139.76 \mathrm{e}$ & $3.181 \pm 0.004 \mathrm{~d}$ & $1.977 \pm 0.097 \mathrm{f}$ & $0.984 \pm 0.047 \mathrm{a}$ & $0.038 \pm 0.002 \mathrm{e}$ \\
WTT & $76.192 \pm 5.40 \mathrm{e}$ & $1133.739 \pm 32.62 \mathrm{e}$ & $3.192 \pm 0.004 \mathrm{c}$ & $3.737 \pm 0.183 \mathrm{c}$ & $0.705 \pm 0.032 \mathrm{~cd}$ & $0.038 \pm 0.002 \mathrm{e}$ \\
TWT & $154.114 \pm 8.17 \mathrm{c}$ & $2022.404 \pm 123.90 \mathrm{~d}$ & $3.194 \pm 0.003 \mathrm{c}$ & $4.208 \pm 0.206 \mathrm{~b}$ & $0.802 \pm 0.037 \mathrm{~b}$ & $0.068 \pm 0.004 \mathrm{c}$ \\
TWW & $182.968 \pm 10.76 \mathrm{~b}$ & $2246.042 \pm 69.52 \mathrm{bc}$ & $3.223 \pm 0.003 \mathrm{~b}$ & $4.785 \pm 0.234 \mathrm{a}$ & $1.045 \pm 0.048 \mathrm{a}$ & $0.075 \pm 0.004 \mathrm{~b}$ \\
WWT & $146.902 \pm 7.71 \mathrm{c}$ & $2181.490 \pm 103.88 \mathrm{~cd}$ & $3.217 \pm 0.006 \mathrm{~b}$ & $4.062 \pm 0.198 \mathrm{~b}$ & $0.763 \pm 0.035 \mathrm{bc}$ & $0.072 \pm 0.003 \mathrm{bc}$ \\
WTW & $183.717 \pm 9.40 \mathrm{~b}$ & $2302.374 \pm 48.92 \mathrm{~b}$ & $3.216 \pm 0.004 \mathrm{~b}$ & $2.661 \pm 0.130 \mathrm{e}$ & $0.550 \pm 0.025 \mathrm{e}$ & $0.077 \pm 0.002 \mathrm{~b}$ \\
WWW & $204.819 \pm 6.02 \mathrm{a}$ & $2514.756 \pm 71.07 \mathrm{a}$ & $3.237 \pm 0.004 \mathrm{a}$ & $2.900 \pm 0.142 \mathrm{e}$ & $0.725 \pm 0.033 \mathrm{~cd}$ & $0.084 \pm 0.004 \mathrm{a}$ \\
\hline \multicolumn{7}{c}{ Significance based on two-way analysis of variance $(\mathbf{A N O V A})(\boldsymbol{F}$ value $)$} \\
\hline W (water type) & $51.168^{* *}$ & $65.147 * *$ & $3.416^{*}$ & $12.643^{* *}$ & $21.214^{* *}$ & $25.617^{* *}$ \\
S (stage) & $12.402^{*}$ & $20.475^{*}$ & 0.714 & 1.246 & 0.604 & $1.574 *$ \\
W $\times$ S & $101.625^{*}$ & $123.622^{*}$ & 1.248 & $8.423^{*}$ & $12.639^{*}$ & $13.978^{* *}$ \\
\hline
\end{tabular}

\section{The effect of different treatments on yield and grain character of winter wheat and summer maize}

The yield and grain character of winter wheat and summer maize under different treatments were shown in Table 7. CK treatment of winter wheat has the highest 1000-grains weight, reaching $42.34 \mathrm{~g}$, followed by WTT, TTW, TWT, WWT, WTW, TWW and WWW treatment. Furthermore, CK treatment of winter wheat has the highest yield, reaching $8007.41 \mathrm{~kg} / \mathrm{hm}^{2}$, followed by WTT, TTW, TWT, WTW, WWT, TWW and WWW treatment.

Table 7. Yield and grain character of winter wheat and summer maize under different treatments

\begin{tabular}{c|cc|ccc}
\hline \multirow{2}{*}{ Treatment } & \multicolumn{2}{|c}{ Winter Wheat } & \multicolumn{3}{c}{ Summer Maize } \\
\cline { 2 - 6 } & $\begin{array}{c}10^{3} \text { Grains } \\
\text { weight }(\mathrm{g})\end{array}$ & $\begin{array}{c}\text { Yield } \\
\left(\mathrm{kg} \cdot \mathrm{hm}^{-2}\right)\end{array}$ & $\begin{array}{c}10^{2} \text { Grains } \\
\text { weight }(\mathrm{g})\end{array}$ & $\begin{array}{c}\text { Cob Weight } \\
(\mathrm{g})\end{array}$ & $\begin{array}{c}\text { Yield } \\
\left(\mathrm{kg} \cdot \mathrm{hm}^{-2}\right)\end{array}$ \\
\hline TTW & $40.29 \pm 0.43 \mathrm{~b}$ & $7824.07 \pm 59.92 \mathrm{ab}$ & $26.94 \pm 0.17 \mathrm{a}$ & $25.91 \pm 0.21 \mathrm{a}$ & $7916.84 \mathrm{abc}$ \\
CK & $42.34 \pm 0.22 \mathrm{a}$ & $8007.41 \pm 77.05 \mathrm{a}$ & $26.96 \pm 0.19 \mathrm{a}$ & $26.07 \pm 0.25 \mathrm{a}$ & $8581.02 \mathrm{a}$ \\
WTT & $41.12 \pm 0.32 \mathrm{ab}$ & $7964.81 \pm 59.92 \mathrm{ab}$ & $26.17 \pm 0.14 \mathrm{ab}$ & $25.17 \pm 0.28 \mathrm{a}$ & $8311.87 \mathrm{ab}$ \\
TWT & $39.98 \pm 0.22 \mathrm{bc}$ & $7751.85 \pm 103.99 \mathrm{~b}$ & $26.16 \pm 0.49 \mathrm{ab}$ & $23.58 \pm 0.32 \mathrm{~b}$ & $8111.24 \mathrm{abc}$ \\
TWW & $38.84 \pm 0.95 \mathrm{~cd}$ & $6629.63 \pm 78.04 \mathrm{de}$ & $25.69 \pm 0.18 \mathrm{~b}$ & $21.92 \pm 0.38 \mathrm{c}$ & $7687.71 \mathrm{bc}$ \\
WWT & $39.88 \pm 0.51 \mathrm{bc}$ & $6825.93 \pm 277.85 \mathrm{~d}$ & $26.21 \pm 1.26 \mathrm{ab}$ & $22.55 \pm 0.37 \mathrm{c}$ & $7869.73 \mathrm{abc}$ \\
WTW & $39.63 \pm 0.70 \mathrm{bc}$ & $7248.15 \pm 120.74 \mathrm{c}$ & $25.75 \pm 0.81 \mathrm{~b}$ & $21.89 \pm 0.77 \mathrm{c}$ & $7583.58 \mathrm{bc}$ \\
WWW & $38.18 \pm 1.43 \mathrm{~d}$ & $6531.48 \pm 97.87 \mathrm{e}$ & $25.64 \pm 0.54 \mathrm{~b}$ & $21.73 \pm 1.09 \mathrm{c}$ & $7327.38 \mathrm{c}$ \\
\hline \multicolumn{7}{c}{ Significance based on two-way analysis of variance (ANOVA) $(\boldsymbol{F}$ value $)$} \\
\hline W (water type) & $6.127^{*}$ & $105.735^{* *}$ & 1.915 & $2.684 *$ & $86.474 * *$ \\
S (stage) & $1.423^{*}$ & $10.474 *$ & 0.682 & 0.547 & $6.457 *$ \\
W $\times$ S & $4.625^{*}$ & $123.612^{* *}$ & 1.036 & 1.376 & $68.927 *$ \\
\hline
\end{tabular}


CK treatment of summer maize has the highest 100-grains weight, reaching $26.96 \mathrm{~g}$, followed by TTW, WWT, WTT, TWT, WTW, TWW and WWW treatment. And cob weight of summer maize in WTT treatment has no significantly difference with CK treatment. Furthermore, CK treatment of winter wheat has the highest yield, reaching $8581.02 \mathrm{~kg} / \mathrm{hm}^{2}$, followed by WTT, TWT, TTW, WWT, TWW, WTW and WWW treatment.

The 1000-grains weight and yield of winter wheat between WTT and CK treatment had no obvious difference, but the values of WTT treatment were significantly higher than TWW, WWW treatment, furthermore, the standard deviation of 1000-grain weight for WTT and CK treatment was only $0.22,0.32$. It indicated that grain filling and yield formation of winter wheat had been slightly affected by the irrigated micro-polluted surface water in emergence stage and groundwater in jointing stage and booting stage, however, yield formation of winter wheat had been obviously affected by the irrigated micro-polluted surface water in jointing stage and booting stage (Gao et al., 2012).

The 100-grains weight and yield of summer maize between WTT, CK, TWT and WWT treatment had no obvious difference, but the values of WTT treatment were significantly higher than that of WTW, TWW and WWW. The results indicated that grain filling and yield formation of summer maize had been stressed from irrigated micro-polluted surface water in the winter wheat booting stage, which may be due to the limited root growth of winter wheat and summer maize under micro-polluted surface water irrigation (Rafiq et al., 2014; Yu et al., 2014).

\section{Correlation analysis between Cd content in summer maize grain and soil layers}

The scatter plot and fit curve between $\mathrm{Cd}$ content in grain and available $\mathrm{Cd}$, total $\mathrm{Cd}$ content in soil layers before summer maize planting were shown in Fig. 2. The determination coefficient of $\mathrm{Cd}$ content in grain and available $\mathrm{Cd}$ in $0-10 \mathrm{~cm}$ soil layer was the highest, reaching 0.9095 , followed by $10-20,20-30,30-40 \mathrm{~cm}$ soil layers, and the determination coefficients were 0.8002, 0.2106, 0.0001, respectively. Furthermore, the determination coefficient of Cd content in grain and total $\mathrm{Cd}$ in $10-20 \mathrm{~cm}$ soil layer was the highest, reaching 0.8081 , followed by $0-10,20-30,30-40 \mathrm{~cm}$ soil layers, and the determination coefficients were $0.7780,0.4802$ and 0.1463 , respectively.
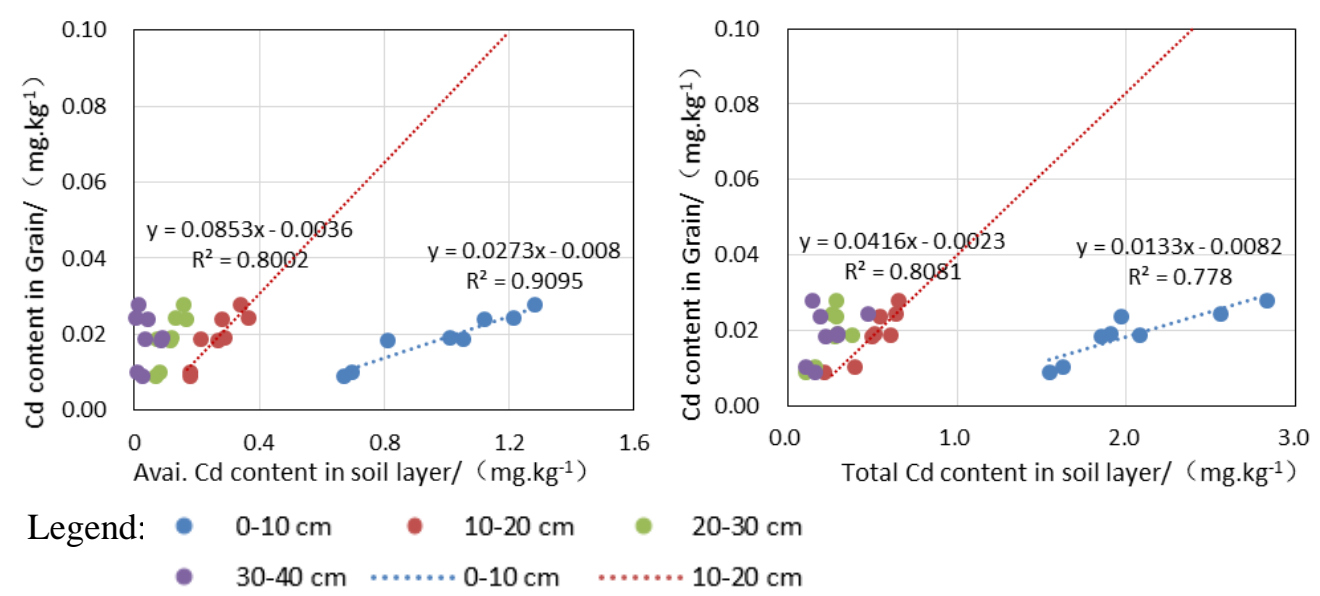

Figure 2. Correlation analysis between $C d$ content in grain and soil layers after summer maize harvest 
The grains Cd limit value specified in National Food Safety Standards of China (GB $2762-2012$ ) is $0.1 \mathrm{mg} / \mathrm{kg}$. According to our prediction model for available Cd content between soil layers and grains, for ensuring the grain $\mathrm{Cd}$ content meets the Standards, the maximum value of available $\mathrm{Cd}$ content in 0 to 10,10 to $20 \mathrm{~cm}$ soil layer was 3.95 , $1.21 \mathrm{mg} / \mathrm{kg}$, respectively. While we choose the prediction models for total cadmium between soil layers and grains, the maximum of total Cd content in 10-20 cm soil layer was a shocking $2.45 \mathrm{mg} / \mathrm{kg}$, and the corresponding available Cd content in 10-20 cm soil layer was reached $1.24 \mathrm{mg} / \mathrm{kg}$ (Zhao et al., 2006; Li et al., 2016). Thus, in order to ensure food security, it is more suitable for us to choose the available cadmium content in 10 to $20 \mathrm{~cm}$ soil layer as the prediction index.

\section{Conclusions}

Content of $\mathrm{Cd}$ in winter wheat and summer maize plants indicated, the value in root was highest, followed by leaves, stem, grain in winter wheat, while the value in root was highest, followed by leaves, corn coating, stem and grain in summer maize.

The Cd content in winter wheat and summer maize grain was lower than the National Standards when crops irrigated with micro-polluted surface water during the emergence stage, and groundwater was adopted during the jointing and booting stage in the study area.

Further work is needed, for example, soil types, fertilizers, precipitation and crop genotypes all affect the expressed model and the threshold range for the available $\mathrm{Cd}$ content in 10-20 cm soil layer, thus, it is necessary to study the effects of irrigation water quality on cadmium induced in winter wheat summer maize rotation system in different soil types and irrigation schedules. The threshold of soil environmental quality of producing areas should be set according to local conditions for ensuring the food safety.

Acknowledgements. This work was funded by Central Public-interest Scientific Institution Basal Research Fund (Grant No.: Y2020GH04), the National Key Research and Development Program of China (Grant No.: 2017YFD0800403) and the Agricultural Science and Technology Innovation Program of Chinese Academy of Agricultural Sciences (Grant No.: CAAS-ASTIP).

\section{REFERENCES}

[1] Amadou, A., Praud, D., Coudon, T., Danjou, A. M. N., Faure, E., Leffondre, K., Le Romancer, M., Severi, G., Salizzoni, P., Mancini, F. R., Fervers, B. (2020): Chronic longterm exposure to cadmium air pollution and breast cancer risk in the French E3N cohort. - International Journal of Cancer 146(2): 341-351.

[2] Andres, S., Ribeyre, F., Tourencq, J. N., Boudou, A. (2000): Interspecific comparison of cadmium and zinc contamination in the organs of four fish species along a polymetallic pollution gradient (Lot River, France). - Science of the Total Environment 248(1): 11-25.

[3] Arefin, M. T., Rahman, M. M., Wahid-U-Zaman, M., Eok, K. J. (2016): Heavy Metal Contamination in Surface Water Used for Irrigation: Functional Assessment of the Turag River in Bangladesh. - Journal of Applied Biological Chemistry 59(1): 83-90.

[4] Chen, X., Cui, Z., Fan, M., Vitousek, P., Zhao, M., Ma, W., Wang, Z., Zhang, W., Yan, X., Yang, J., Deng, X., Gao, Q., Zhang, Q., Guo, S., Ren, J., Li, S., Ye, Y., Wang, Z., Huang, J., Tang, Q., Sun, Y., Peng, X., Zhang, J., He, M., Zhu, Y., Xue, J., Wang, G., Wu, 
L., An, N., Wu, L., Ma, L., Zhang, W., Zhang, F. (2014): Producing more grain with lower environmental costs. - Nature 514(7523): 486-489.

[5] Chen, N., Zheng, Y., He, X., Li, X., Zhang, X. (2017): Analysis of the report on the national general survey of soil contamination. - Journal of Agro-Environment Science 36(9): 1689-1692.

[6] Franz, E., Romkens, P., van Raamsdonk, L., Van der Fels-Klerx, I. (2008): A Chain Modeling Approach to Estimate the Impact of Soil Cadmium Pollution on Human Dietary Exposure. - Journal of Food Protection 71(12): 2504-2513.

[7] Gao, X., Lukow, O. M., Grant, C. A. (2012): Grain concentrations of protein, iron and zinc and bread making quality in spring wheat as affected by seeding date and nitrogen fertilizer management. - Journal of Geochemical Exploration 121: 36-44.

[8] Hu, Y., Li, P., Qi, X., Li, Z., Hu, C., Zhao, Z. (2016): Analysis of Winter Wheat Sensitive Period for Cd under Rotational Irrigation with Clean Water and Polluted Water. - Journal of Irrigation and Drainage 35(8): 21-24.

[9] Huang, Y., Wang, L., Wang, W., Li, T., He, Z., Yang, X. (2019): Current status of agricultural soil pollution by heavy metals in China: A meta-analysis. - Science of the Total Environment 651: 3034-3042.

[10] Hundecha, Y., Bardossy, A. (2005): Trends in daily precipitation and temperature extremes across western Germany in the second half of the 20th century. - International Journal of Climatology 25(9): 1189-1202.

[11] Jiang, K., Long, J., Li, X., Dong, X., Wang, S., Liu, W., Hou, H., Peng, P., Liao, B. (2019): Effects of exogenous $\mathrm{Cl}$-on $\mathrm{Cd} \sim(2+)$ concentrations in soil solutions of different soil types. - Acta Scientiae Circumstantiae 39(2): 553-559.

[12] Kong, X., Zhang, X., Lal, R., Zhang, F., Chen, X., Niu, Z., Han, L., Song, W. (2016): Groundwater Depletion by Agricultural Intensification in China's HHH Plains, Since 1980s. - Advances in Agronomy 135: 59-106.

[13] Li, J., Li, F., Liu, Q., Song, S., Zhang, Y., Zhao, G. (2014): Impacts of Yellow River Irrigation Practices on Trace Metals in Surface Water: A Case Study of the HenanLiaocheng Irrigation Area, China. - Human and Ecological Risk Assessment 20(4): 10421057.

[14] Li, P., Qi, X., Magzum, N., Huang, Z., Liang, Z., Qiao, D. (2015): Response of precipitation to ratio of canal to wells and its environmental effects analysis in combined well-canal irrigation area. - Transactions of the Chinese Society of Agricultural Engineering 31(11): 123-128.

[15] Li, F., Wen, D., Wang, F., Wang, X., Wan, K., Liu, X. (2016): Correlation Analysis of Cd Pollution between Soil and Brassica Leaf Vegetables and the Soil Cd Safety Threshold in Guangdong Region. - Ecology and Environmental Sciences 25(4): 705-710.

[16] Li, Y., Xie, Z., Qin, Y., Zhou, S. (2018): Spatio-temporal variations in precipitation on the Huang-Huai-Hai Plain from 1963 to 2012. - Journal of Earth System Science 127(7): 101.

[17] Peng, H., Chen, Y., Weng, L., Ma, J., Ma, Y., Li, Y., Islam, M. S. (2019): Comparisons of heavy metal input inventory in agricultural soils in North and South China: A review. Science of the Total Environment 660: 776-786.

[18] Rafiq, M. T., Aziz, R., Yang, X., Xiao, W., Rafiq, M. K., Ali, B., Li, T. (2014): Cadmium phytoavailability to rice (Oryza sativa L.) grown in representative Chinese soils. A model to improve soil environmental quality guidelines for food safety. - Ecotoxicology and Environmental Safety 103: 101-107.

[19] Rhoades, J. D., Manteghi, N. A., Shouse, P. J., Alves, W. J. (1989): Soil electrical conductivity and soil salinity: new formulations and calibrations. - Soil Science Society of America Journal 53(2): 433-439.

[20] Safahieh, A. (2018): Investigation on bio-concentration factor (BCF) and bioaccumulation factor (BAF) of aromatic compounds in the Ark clam. - Journal of Natural Environment 71(2): 227-236. 
[21] Satarug, S., Baker, J. R., Urbenjapol, S., Haswell-Elkins, M., Reilly, P. E. B., Williams, D. J., Moore, M. R. (2003): A global perspective on cadmium pollution and toxicity in non-occupationally exposed population. - Toxicology Letters 137(1-2): 65-83.

[22] Shang, E., Xu, E., Zhang, H., Huang, C. (2018): Spatial-Temporal Trends and Pollution Source Analysis for Heavy Metal Contamination of Cultivated Soils in Five Major Grain Producing Regions of China. - Environmental Science 39(10): 4670-4683.

[23] Smaoui-Damak, W., Rebai, T., Berthet, B., Hamza-Chaffai, A. (2006): Does cadmium pollution affect reproduction in the clam Ruditapes decussatus? A one-year case study. Comparative Biochemistry and Physiology C-Toxicology \& Pharmacology 143(2): 252261.

[24] Wang, Z., Li, J., Li, Y. (2017): Using Reclaimed Water for Agricultural and Landscape Irrigation in China: A Review. - Irrigation and Drainage 66(5): 672-686.

[25] Wang, G., Luo, Z., Wang, E., Zhang, W. (2018a): Reducing greenhouse gas emissions while maintaining yield in the croplands of Huang-Huai-Hai Plain, China. - Agricultural and Forest Meteorology 260: 80-94.

[26] Wang, G., Yan, D., He, X., Liu, S., Zhang, C., Xing, Z., Kan, G., Qin, T., Ren, M., Li, H. (2018b): Trends in extreme temperature indices in Huang-Huai-Hai River Basin of China during 1961-2014. - Theoretical and Applied Climatology 134(1-2): 51-65.

[27] Yadav, P., Garg, V. K., Singh, B., Mor, S. (2017): Assessment of Bio-Concentration Factor of Heavy Metals in Indian Soil-Crop System. - Journal of Scientific \& Industrial Research 76(6): 381-385.

[28] Yang, Q., Li, Z., Lu, X., Duan, Q., Huang, L., Bi, J. (2018): A review of soil heavy metal pollution from industrial and agricultural regions in China: Pollution and risk assessment. - Science of the Total Environment 642: 690-700.

[29] Yin, J., Yan, D., Yang, Z., Yuan, Z., Yuan, Y., Zhang, C. (2016): Projection of extreme precipitation in the context of climate change in Huang-Huai-Hai region, China. - Journal of Earth System Science 125(2): 417-429.

[30] Yin, W., Hu, L., Jiao, J. (2017): Evaluation of groundwater storage variations in Northern China using GRACE data. - Geofluids 2017: 8254824.

[31] Yu, L., Zhu, J., Huang, Q., Su, D., Jiang, R., Li, H. (2014): Application of a rotation system to oilseed rape and rice fields in Cd-contaminated agricultural land to ensure food safety. - Ecotoxicology and Environmental Safety 108: 287-293.

[32] Zhang, P., Qin, C., Hong, X., Kang, G., Qin, M., Yang, D., Pang, B., Li, Y., He, J., Dick, R. P. (2018): Risk assessment and source analysis of soil heavy metal pollution from lower reaches of Yellow River irrigation in China. - Science of the Total Environment 633: 1136-1147.

[33] Zhao, Y., Li, H., Sun, Z. (2006): Correlation analysis of Cd pollution in vegetables and soils and the soil pollution threshold. - Transactions of the Chinese Society of Agricultural Engineering 22(7): 149-153. 